\title{
SEISMIC STRENGTHENING OF EXISTING RC BUILDINGS STRUCTURES USING CONCRETE JACKETING AND FRP MATERIALS
}

Professional paper / Stručni rad

\section{Golubka Nechevska-Cvetanovska}

(Received: 18 July 2019; accepted: 9 December 2019)

UKIM-ZIIS-Skopje, R.N.Macedonia, Professor

Corresponding author: golubka@pluto.iziis.ukim.edu.mk

Arthur Roshi

UKIM-IZIIS-Skopje, R.N.Macedonia, Metropolitan university, Tirana, Albania, PhD student, Julijana Bojadjieva

UKIM-IZIIS-Skopje, R.N.Macedonia, Assistant Professor

\begin{abstract}
The need for repairing and strengthening RC buildings and their structural elements occurs when their elements do not possess sufficient strength, stiffness, and/or ductility due to damage mostly caused by earthquakes. Within the scope of this study, special emphasis will be given to RC buildings where the built-in concrete has not achieved the designed concrete class during construction and/or buildings that cannot satisfy the required strength, stiffness, and deformation characteristics particularly in earthquake conditions owing to construction of additional storeys or enlargements. In such cases, it is necessary to repair and strengthen both individual structural elements and whole structures using traditional (concrete jacketing) and innovative (FRP) materials.
\end{abstract}

Keywords: concrete quality; repair and strengthening; traditional and innovative materials; concrete jacketing; FRP

\section{PROTUPOTRESNO OJAČANJE POSTOJEĆIH AB KONSTRUKCIJA POMOĆU INJEKTIRANJA BETONA I FRP MATERIJALA}

Sažetak: Do potrebe za popravkom i ojačanjem AB zgrada i njihovih konstruktivnih elemenata dolazi kada one ne posjeduju dostatnu čvrstoću, krutost i/lil duktilnost zbog oštećenja nastalih uslijed djelovanja potresa. U okviru ove studije, poseban naglasak će bit na AB konstrukcijama kod kojih ugrađeni beton nije dostigao projektiranu klasu betona tjekom gradnje i/li na zgradama koje ne mogu udovoljit traženim svojstvima čvrstoće, krutosti i deformacije, posebno u uvjetima potresnog opterećenja zbog izgradnje dodatnih katova ili nadogradnji. U takvim je slučajevima potrebno popraviti i ojačati i pojedine konstrukcijske elemente i cijelu konstrukciju koristeći tradicionalne metode (betonsko injektiranje) i inovativne (FRP) materijale.

Ključne riječi: kvaliteta betona; popravak i ojačanje; tradicionalni i inovativni materijali; betonsko injektiranje; FRP 


\section{INTRODUCTION}

Reinforced concrete $(\mathrm{RC})$ is a composite material made of concrete and steel reinforcement. Concrete is composed of cement, filler, and water as well as corresponding additives for improving its characteristics.

The structure of concrete is quite complex, and its main components should be carefully selected using all available techniques to provide the corresponding necessary quality.

Despite the great advancement in the field of construction technology, control of built-in materials (quality of cement, filler, and water), transport, and layering of concrete, it often happens that the built-in concrete does not reach the designed concrete class. Sometimes, this deviation is of a larger scale. Therefore it is necessary to anticipate and take measures for repairing and strengthening that may be used for a smaller or a greater number of structural elements and the structure as a whole. The same problem may also occur during construction of additional storeys and enlargements. For this case, the existing structural system cannot satisfy the requirements for additional strength, stiffness, and deformation capacity.

It is a usual practice to repair and strengthen structures by using traditional methods (most frequently, jacketing of elements). Recently, new innovative materials that use special construction technology are being applied to repair structures. The application of these materials is sill the subject of a large number of investigations worldwide, especially regarding their ubilization in seismically active regions.

\section{REPAIR AND STRENGTHENING OF BUILDINGS STRUCTURES}

Strengthening of RC structural elements is an existing method to increase the earthquake resistance capacity of damaged or undamaged buildings. The strength of these structures can be moderately or significantly increased along with an improvement in ductility. In other words, the concept of strengthening involves: a) increase in strength, b) increase in strength and ductility and c) increase in ductility, (Figure 1).

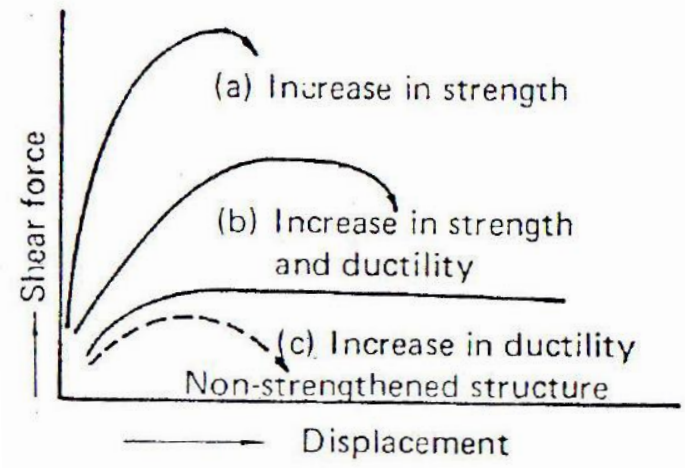

Figure 1 Concept of seismic strengthening

The methods for repair and strengthening of structures can be categorized into two main groups: system based repair and strengthening (global strengthening) and member based strengthening (local strengthening).

In system based strengthening methods, a structural system is modified by adding members such as RC shear walls or additional steel bracing to improve the strength and stifness characteristics of the building system.

A new frame can be introduced to increase the lateral strength and stiffness of a building. Similar to a new wall, integrating a new frame building and providing foundations are critical design issues.

The local strengthening approach involves the modification of deficient elements to increase ductility so that the deficient elements can reach their limit state in a ductile manner when subjected to design events.

The methods of strengthening RC columns in building structures using traditional methods (concreting and steel jacketing) and strengthening of RC building structures using innovative FRP materials will be discussed further in this study. In the end, two examples of application of FRP materials for repair and strengthening of RC structures are presented. Additionally, the conclusions are presented in tables for emphasizing the advantages and drawbacks of different techniques for global and local strengthening of RC building structures. 


\section{REPAIR AND STRENGTHENING OF COLUMNS USING TRADITIONAL MATERIALS}

\subsection{Column strengthening}

The purpose of column strengthening is to improve the strength and deformability capacity of damaged or undamaged buildings. During the construction phase, when there is failure of concrete or any other substantial material in reaching the required quality as per the design, strengthening of specific structural members will be required. Increased resistance of columns means increase in flexural and shear strength of columns along with an improvement in ductility by applying different techniques of strengthening.

For damaged columns, depending on the degree and type of damage, different techniques, such as resin injection, removal and replacement, or jacketing may be applied. This depends on whether it is necessary to increase or achieve the same strength and deformability capacity of the columns prior to the damage.

\subsubsection{RC jacketing}

One of the most frequently applied methods used for strengthening reinforced concrete columns is the concrete jacketing method (Figure 2 and Figure 3).

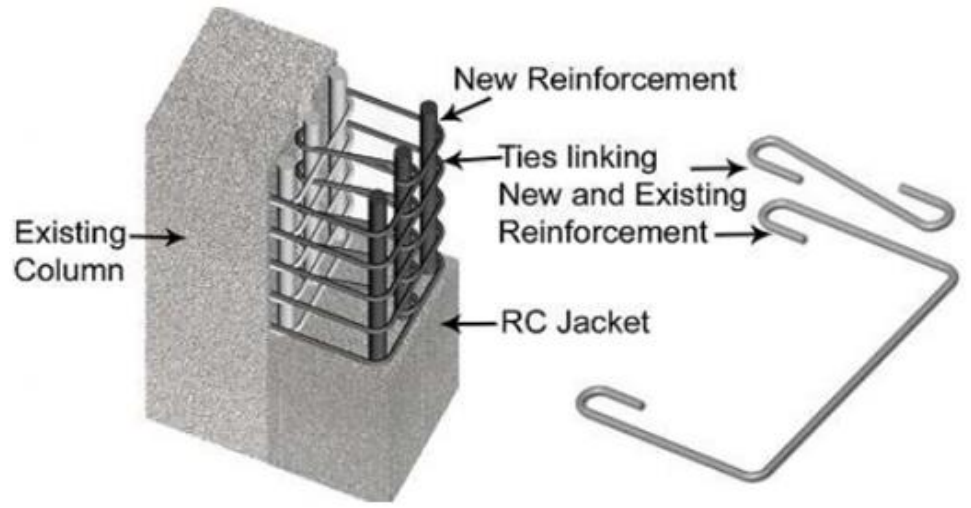

Figure 2 Reinforced concrete jacketing of existing column (M., Fardis [11])

$\mathrm{RC}$ jacketing can be defined as the confinement of an $\mathrm{RC}$ column with new reinforced concrete elements. It may be implemented for various purposes based on the type of structural deficiency of the member. Columns subjected to brittle failure can be jacketed to enhance resistance against shear, bending, and axial loads. Here, although the purpose of RC jacketing is only to increase the axial load or shear strength, some changes will also occur in the bending stiffness and moment capacity of the member after jacketing. By considering these changes during the jacketing design, the jacketed section is ensured to achieve adequate shear and axial load strength.

Except for brittle damages, jacketing is applied for elements with inadequate bending capacity or ductility. This way, the strength of the columns displaying a splice failure as a result of bending can also be improved. Jacketing of the columns produces the best result if it is implemented at all 4 sides of the column. When necessary, confinement at only 3 sides can also provide adequate performance. However, it is not generally recommended to implement jacketing at 1 or 2 sides because no significant changes take place in the confinement characteristics of the member. 


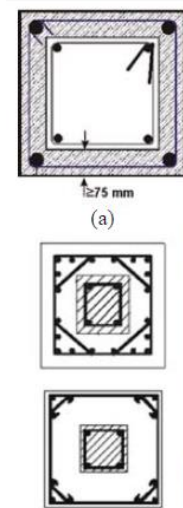

(b)
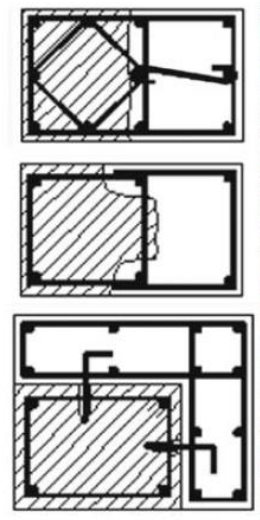

(f)

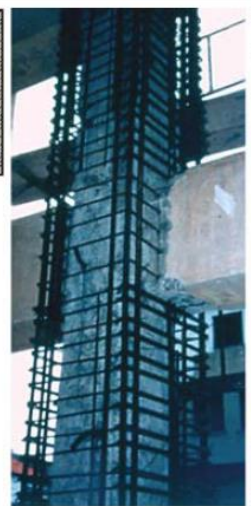

(c)

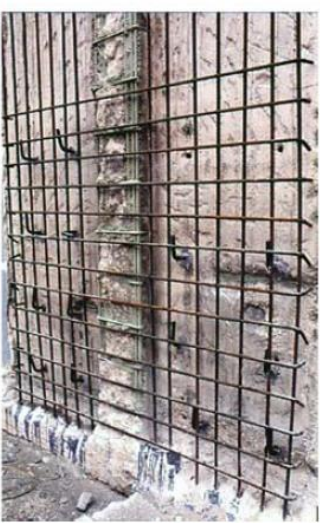

$(\mathrm{g})$

Figure 3 Concrete jackets in columns: a) simplest case b) jacket bars bundled near corners, engaged by cross-ties or orthogonal tie c) jacket bars bundled at corners, dowels at interface with old column d) $U$ bars welded to corner bars e) steel plates welded to corner bars f) one-or two-sided jackets g) one-sided concrete overlay with single curtain of two way reinforcement at exterior face of perimeter walls $(M$., Fardis [11])

\subsubsection{Steel jackets}

Jacketing with steel elements is a practical method used frequently for various applications. A typical steel jacketing application is presented in Figure 4.

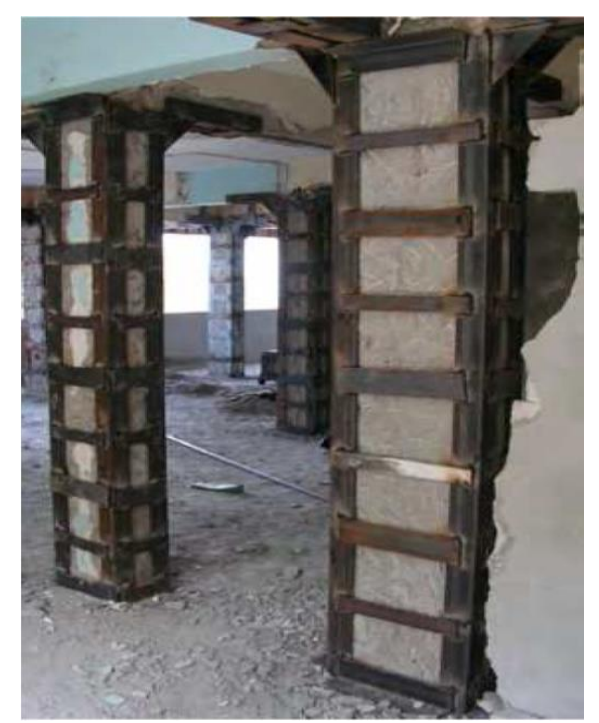

Figure 4 Steel jacketing applied to RC columns (P.Gavrilovic [14])

Nechevska Cvetanovska G., Roshi A., Bojadjieva, J. 
Steel jacketing can be readily used to enhance the shear strength and ductility of reinforced concrete elements with minimum increase in size. Located at the corners of an element, L-profiles are coupled by means of steel plates and confined. With the maintenance of continuity between storeys, steel jacketing can be used to increase the bending strength. The maintenance of adequate strength between the steel element and the reinforced concrete element is inevitable for the improvement of bending capacity. The setbacks of this method are: 1) it requires protection against corrosion and fire. 2) It is costlier than concrete jacketing and needs skilled workers.

\section{REPAIR AND STRENGTHENING OF BUILDINGS USING INNOVATIVE MATERIALS}

\subsection{Fiber Reinforced Polymers (FRP)}

FRP composites comprise high tensile strength fibers within a polymer matrix. Generally, carbon or glass fibers are present in a matrix, such as vinyl ester or epoxy. These materials are manufactured to form plates under factory conditions, generally by a pultrusion process.

The primary materials in a composite are the reinforcement fibers and polymer matrix. Other materials are incorporated in the composite, but are less significant in terms of cost and effect on properties. The term polymer composites include both thermosetting and thermoplastic resins. The most commonly used thermosetting resins in composites are polyester, urethane methacrylate, vinyl ester, epoxy, and phenolic. These materials are isotropic materials and allow load transfer between fibers. The matrix protects the notch-sensitive fibers from abrasion, and forms a protective barrier between the fibers and the environment, thus preventing an attack from moisture, chemicals, and oxidation. It also plays an important role in providing shear, transverse tensile, and compression properties. The thermomechanical performance of the composite is also governed by the matrix performance.

Reinforcement fibers are classified in three main families: glass, aramid, and carbon. There are other fibers, which are relatively insignificant. The most important property of the fibers is their elastic modulus. The fibers must be significantly stiffer than the matrix which allows them to carry most of the stress. Consequently, they must also have high strength. Reinforcements are available in a variety of configurations. However, there are three main categories:

- Unidirectional, where all the fibers lie in one direction.

- Bidirectional, where the fibers lie at $90^{\circ}$ to one another. This is achieved either by use of woven fabric, non-woven fabric or by using separate layers of fibers that are unidirectional, but successively laid at $90^{\circ}$.

- $\quad$ Random, where the fibers are randomly distributed in-plane.

Stress-strain fiber behaviour is different for every type of fiber. (Figure 5). Different FRP shapes (Figure 6) and Different material properties are given in Table 1.

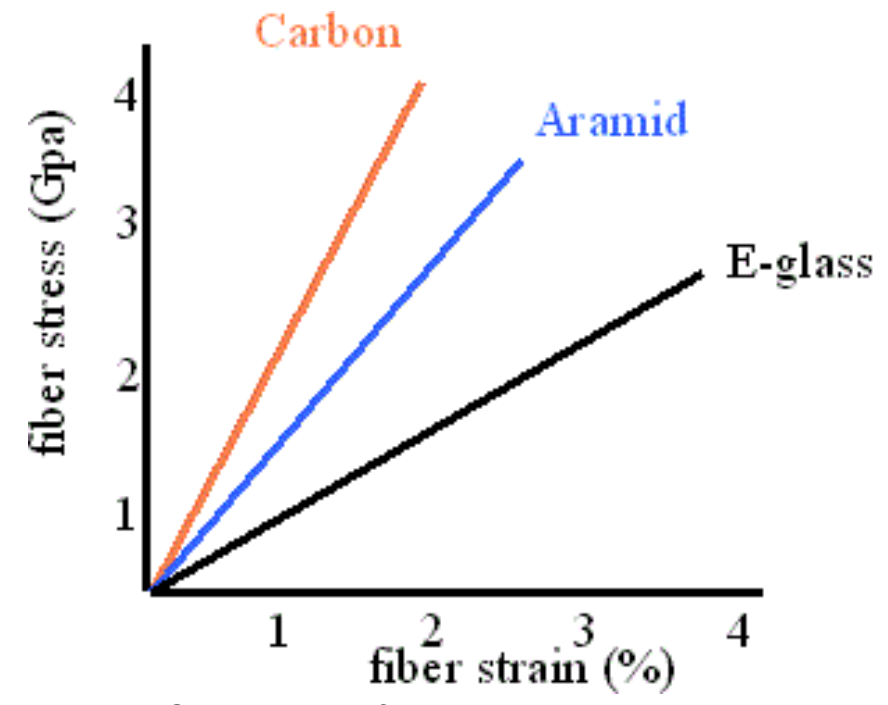

Figure 5 Stress- strain fiber behavior (A. Prota [19])

Nechevska Cvetanovska G., Roshi A., Bojadjieva, J. 

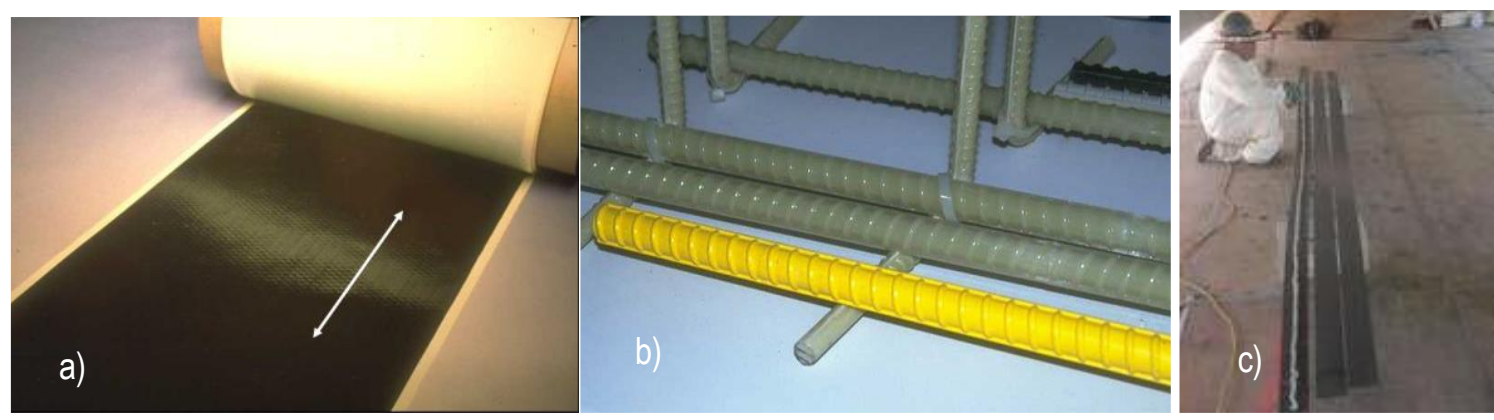

Figure 6 Different FRP shapes a) sheet b) bars c) pre cured laminate (A. Prota [19])

Table 1 FRP materials - Fiber comparison

\begin{tabular}{lcccc}
\hline & Strength & Modulus & Moisture and chemical resistance & Cost \\
\hline Carbon & High & High & Excellent & High \\
Aramid & High & Intermediate & Good & High \\
E-Glass & High & Low & Low & Low \\
\hline
\end{tabular}

\subsection{Repair and strengthening of an existing building using FRP}

The application of FRP materials for strengthening RC building structures enables the achievement of a greater deformability capacity (ductility) of the structures. This way, the seismic resistance, shear, and flexural strength of the building structures can be increased by minimal increase in the cross-sectional dimension.

In the strengthening procedure, the following is assumed:

- The choice and design of the adopted strengthening system is made by an appropriately qualified and experienced engineer.

- The installation process is carried out by personnel having appropriate skills and experience.

- Proper supervision and quality control is provided during installation.

- Construction materials are used as specified in the following.

The FRP strengthening system should be designed to have appropriate strength, and satisfy serviceability and durability requirements. In case of fire, the strength of the selected FRP strengthening system has to be adequate for the required period of time.

The FRP strengthening system will be located in certain areas where tensile stresses will be carried out. FRP composites cannot be relied upon for carrying compressive stresses.

Design of FRP strengthening system should be performed in compliance with the following principles:

- The risks to which the structure can be subjected to shall be accurately identified, removed, or attenuated before the process.

- The strengthening configuration should not be very sensitive to the above risks.

- Strengthening systems should survive the occurrence of acceptable localized damages.

- Strengthening systems that collapses without previous warning shall be avoided.

The above defined basic requirements can be fulfilled if the following conditions are satisfied:

- Suitable materials are chosen.

- Design is properly executed with an adequate choice of construction details.

- Quality control procedures are defined for design and construction adequate to the particular project.

\subsection{Strengthening design principles}

Design with FRP composites should be carried out in terms of serviceability limit state (SLS) and ultimate limit state (ULS) defined by the current building codes. Structures and structural members strengthened with FRP should be designed to have the design strength, $R_{d}$, at all sections at least equal to the required strength, $E_{d}$, calculated for the factored load and forces in combinations as per the current building codes. The following expression represents the foregoing:

$E_{d} \leq R_{d}$

Nechevska Cvetanovska G., Roshi A., Bojadjieva, J. 
The design values are obtained from the characteristic values through appropriate partial factors that are different for each limit state as indicated in the current building code. Specific partial factors for FRP materials are indicated in a specific document. For structural applications using FRP to be carried out on single structural members, when the conditions for upgrading are not met, it shall be proven that the adopted strengthening method provides the structure with a significant level of safety with respect to the applied loads.

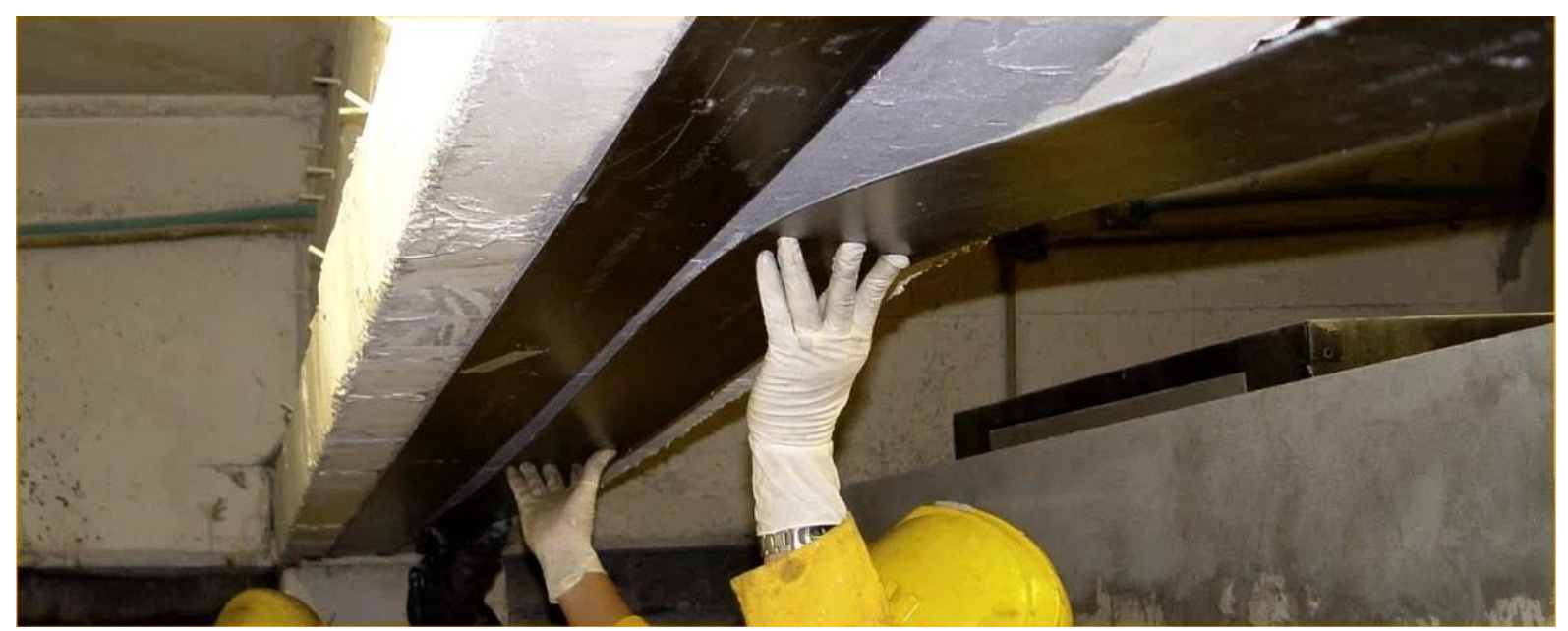

Figure 7 Flexural strengthening (CNR-DT [7])

Flexural design of FRP strengthened members (Figure 7) requires that both flexural capacity, MRd, and factored ultimate moment, MSd, satisfy the following expression:

$M_{S d} \leq M_{R d}$

Design at ULS of FRP confined members requires factored design axial load, $N_{S d}$, and factored axial capacity, $N_{R c c, d}$ to satisfy the following expression:

$N_{S d} \leq N_{R C C, d}$

\subsubsection{Confinement strengthening}

Confinement strengthening (Figure 8) consists of:

- Cleaning and repair

- Primer

- Adhesive

- FRP strips

- Last adhesive layer
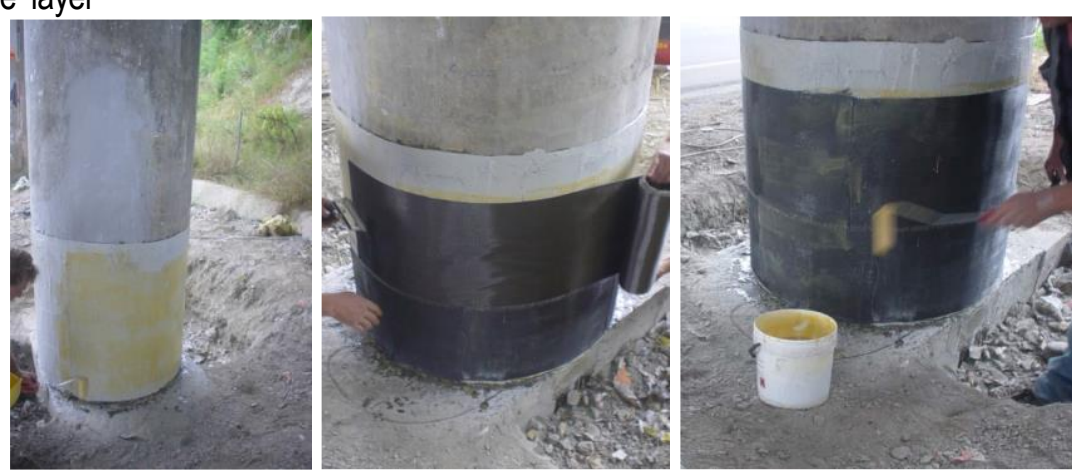

Figure 8 Confinement strengthening (Di Ludovico M [20])

The difference between concrete jacketing and FRP wrapping is that FRP jacketing increases member ductility while concrete jacketing increases ductility and strength (Figure 9). 


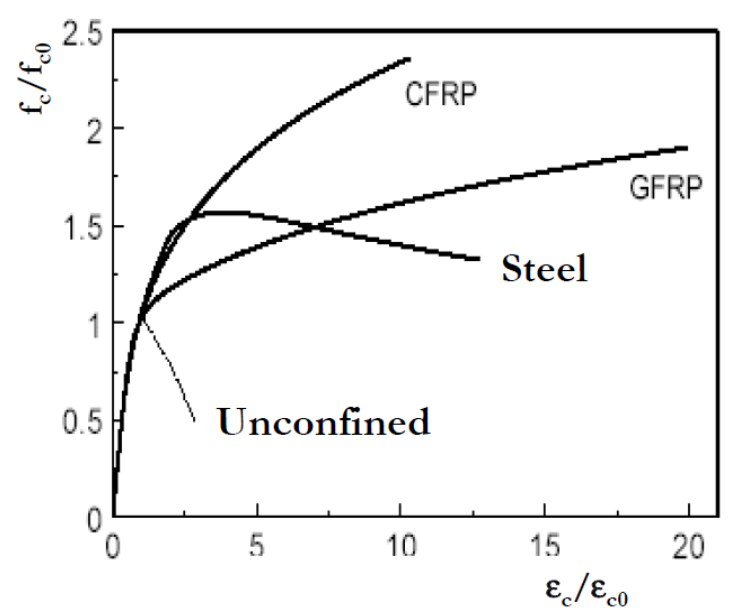

Figure 9 Effect of confining for different device material

\subsubsection{Seismic strengthening with FRP}

The most strictly connected aspect of the hazard in southern European countries is represented by a number of existing RC structures that are under-designed or designed using old codes and construction practices. Casualties and losses occur mainly due to deficient RC buildings that are not adequately designed for earthquake resistance.

One way to increase seismic resistance of the structures is strengthening with FRP materials.

Regarding the type and size of selected FRP systems and urgency of FRP installation, the following shall be taken into account:

(1) Common errors shall be eliminated

(2) Major building irregularities cannot be eliminated using FRP as a strengthening technique

(3) A better resistance regularity can be obtained by strengthening local ductility

(4) Localized strengthening shall not reduce the overall ductility of the structure

The FRP seismic strengthening strategy is based on the following principles:

1) Avoiding britte failure mechanisms

- Shear failure

- Lap splice failure

- Instability of longitudinal reinforcement in compression

2) Avoiding soff-storey mechanisms

3) Increasing the global deformation capacity by:

- Enhancing the ductility of plastic hinges

- Relocalizing plastic hinges

To perform local strengthening, external joints of a structure should be strengthened by satisfying the previously stated principles, (Figure 10).

(1) Diagonal uniaxial steel sheets are designed

(2) Quadriaxial CFRP sheet increases shear strength

(3) Column end confinement using CFRP uniaxial sheets (Concrete ultimate strain increases and thus the curvature and rotational capacity increases)

(4) U-shaped sheets on beams 


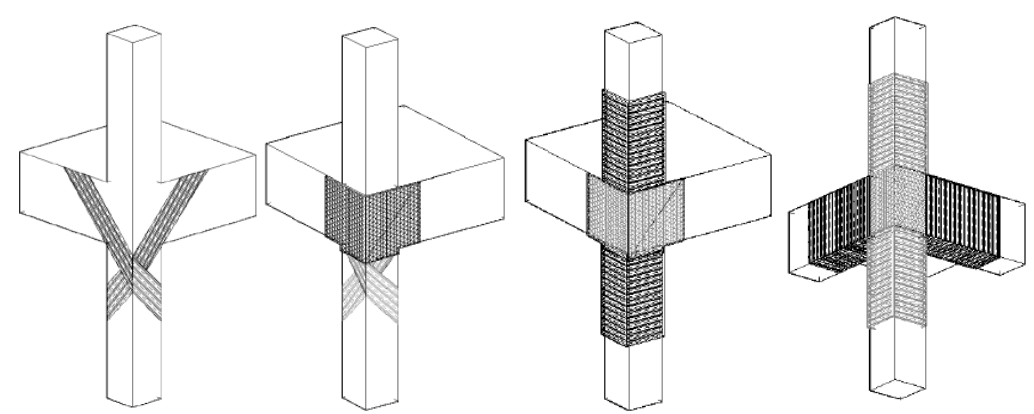

Figure 10 Seismic strengthening of external joints using CFRP sheets (Ozcebe, G. [4])

The decision for selecting the type of FRP material for the repair and/or strengthening process of the structural elements of the RC building structure can be made after a detailed analysis of the bearing capacity and deformability of the damaged and non-damaged elements of the RC structures is performed. In doing so, a detailed diagnosis should be performed regarding the reasons necessary for repair and strengthening of the structural elements. It should be defined whether a structure is damaged by an external phenomenon (for example, earthquake) or due to sub-standard quality of built-in materials lower than the designed specifications (for instance, lower class concrete or insufficient reinforcement). Based on the above conclusions, the type of FRP material will be selected. For instance, carbon FRP is characterized by high strength, high modulus of elasticity, and excellent chemical resistance. However, its deformability capacity is much lower than that of aramid and e-glass. On the other hand, e-glass has a lower strength capacity, but a much greater deformability capacity. The price may certainly have a greater role in the selection of the material to be used. After defining the scope of work, (it can be a combination of FRP and concrete), additional analysis should be performed again to check whether the new strengthened structural system satisfies all the requirement prescribed by the existing regulations. FRP materials are sill the subject of a lot of investigations, especially regarding their use in seismically active regions.

\subsection{Examples}

Presented further in the text are two examples showing that the application of CFRP in strengthening RC structural elements enables improvement in strength and deformability capacity of the global structural system. In the first example, the strengthening was performed by using CFRP for the infill of an RC building, while in the second example, strengthening was done on RC columns of a substandard RC building. More details on these examples are given further in the paper.

\subsubsection{Nato project}

Within the NATO Science for Peace Project of "Seismic Assessment and Rehabilitation of Existing Buildings" [22], three $1 / 3$ scale models (2 storey RC frame specimens) of a 4 storey RC frame building prototype were designed, constructed, and tested on the shaking-table in the IZIIS Laboratory, Skopje, Macedonia. The main goal was to verify the validity and applicability of different seismic retrofitting techniques. Taking into account the similitude requirements, artificial mass simulation was applied as a method for model design of the specimens. Accordingly, the time scale and intensity of earthquake records were altered to ensure that the shaking table motion would produce the required inelastic behavior of the models. The first test specimen was a pure 3D RC frame structure with infill walls. The second specimen had additional CFRP strips applied on the inner and outer faces of the infill walls using epoxy resin (Figure 11). The retrofiting technique proposed for the third specimen involved pre-cast concrete panels of epoxy glued to the walls and frame members. 


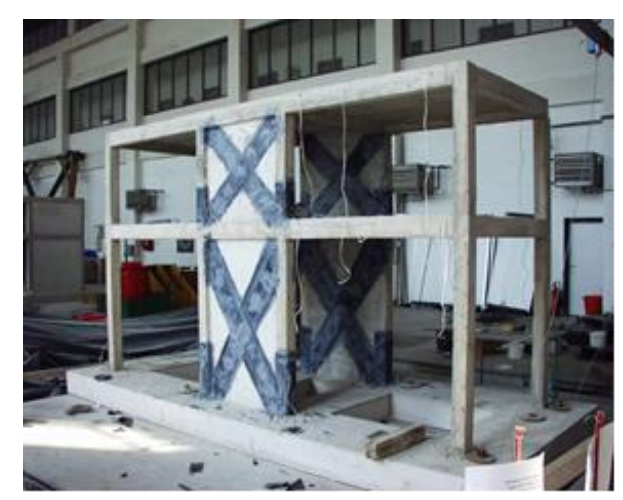

Figure 11 Completed model with added carbon fibers (NATO SfP 977231 [22])

The results obtained from the specimen show that the proposed retrofit techniques can improve the behavior of RC structures by increasing their strength and ductility. The experimental investigations provided a large contribution to the field of building strengthening by CFRP strips.

\subsubsection{ITU-DovAksa Full-Scale Building}

A test was conducted on CFRP retrofitting at ITU University, Turkey, by Prof. Dr. Alper Ilki from ITU University and his team for the project titted "Efficiency of Seismic Retrofit with CFRPS through Full Scale Site Testing of Substandard RC Structures (2016)". A photo presentation is given in the figures below (Figure $12 \mathrm{a}, \mathrm{b}, \mathrm{c}$ ).

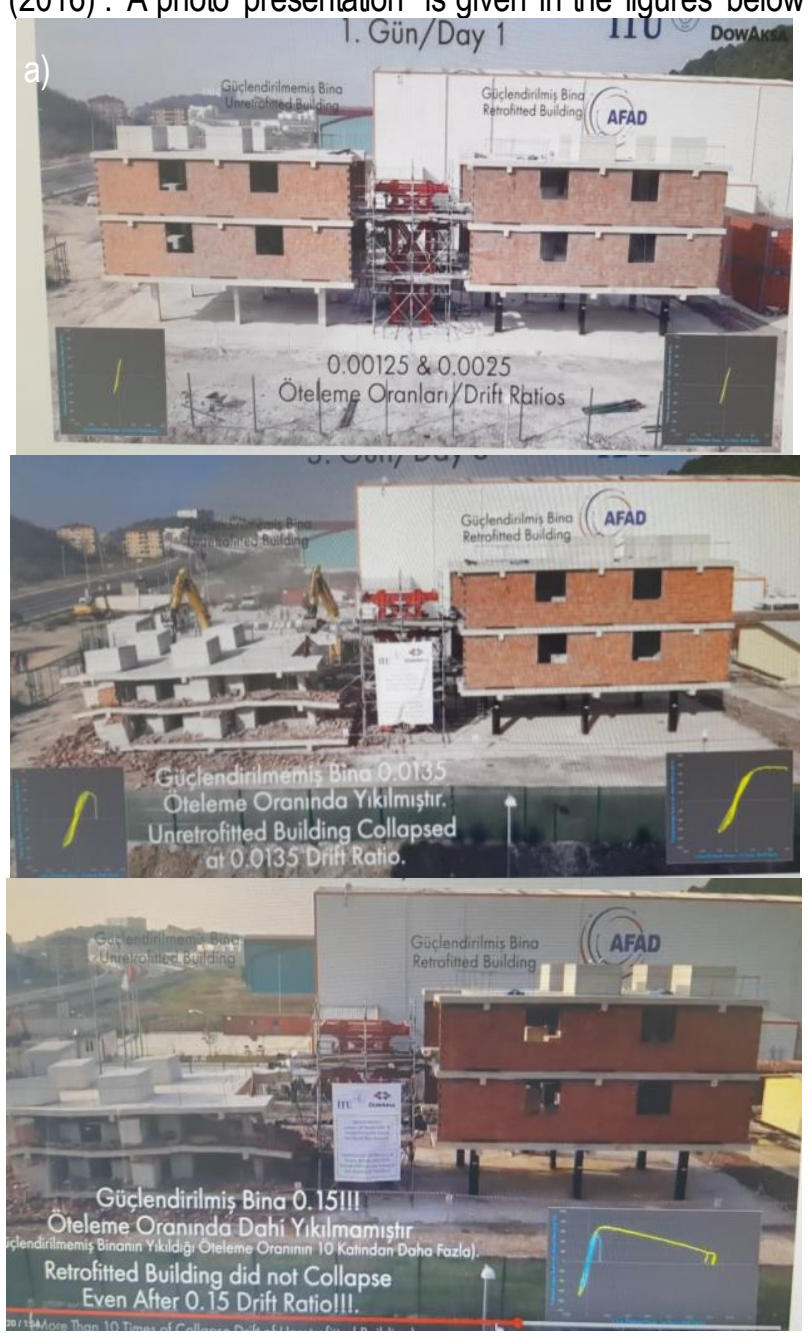

Figure 12 a), b), c) Efficiency of seismic retrofit with CFRPS through full scale site testing of substandard RC structures - Day 1, Day2 and Day 3, respectively [34]

Nechevska Cvetanovska G., Roshi A., Bojadjieva, J. 
The results of the experimental investigation concluded that the building that was not retrofitted collapsed at a 0.0135 drift ratio, while the retrofitted building did not collapse even at a dritt ratio of 0.15 .

\section{CONCLUSION}

The conclusions are listed in tables 2 and 3, providing insight into the advantages and disadvantages of different types of repair and strengthening.

The global retrofit strategies are presented in Table 2 with their advantages and drawbacks. For example, the addition of infill walls can result in increased lateral stiffness. Infill walls are easy to implement and can experience premature failure due to dislodging and crushing. It increases the weight of the structure without increasing ductility. Other strategies require integration with the existing system with the exception of those including braces. They require adequate foundation, which makes them more expensive. Nevertheless, it increases the overall ductility of the system.

Table 3 shows the comparison between local retrofit strategies of concrete jacketing, steel jacketing of columns, bonding steel plates to beams, and fiber reinforced polymer wrapping. For example, when using concrete and FRP jacketing, both methods can increase the ductility of the cross section as well as the flexural and shear strength. In geometry, FRP wrapping results in a minimal increase in size of the cross section compared to concrete jacketing. However, FRP requires proper fire protection, skilled labor force, and can be more expensive.

More details on the above strategies are listed in the tables below.

Table 2 Comparative evaluation of the global retrofit strategies

\begin{tabular}{|c|c|c|c|}
\hline $\begin{array}{c}\text { Strengthening } \\
\text { strategy }\end{array}$ & Merits & Demerits & Comments \\
\hline $\begin{array}{l}\text { Addition of } \\
\text { infill walls }\end{array}$ & $\begin{array}{l}\text { Increases lateral stiffness } \\
\text { of a storey. } \\
\text { Can support vertical load } \\
\text { if adjacent column fails. }\end{array}$ & $\begin{array}{l}\text { May have premature failure due to } \\
\text { crushing of corners or dislodging. } \\
\text { Does not increase ductility. } \\
\text { Increases weight. }\end{array}$ & $\begin{array}{l}\text { Low cost. } \\
\text { Low disruption. } \\
\text { Easy to implement. }\end{array}$ \\
\hline $\begin{array}{l}\text { Addition of } \\
\text { shear walls, } \\
\text { wing walls and } \\
\text { buttress walls }\end{array}$ & $\begin{array}{l}\text { Increases lateral strength } \\
\text { and stiffness of the } \\
\text { building substantially. } \\
\text { May increase ductility. }\end{array}$ & $\begin{array}{l}\text { May increase design base shear. } \\
\text { Increase in lateral resistance is } \\
\text { concentrated near the walls. } \\
\text { Needs adequate foundation. }\end{array}$ & $\begin{array}{l}\text { Needs integration of the walls to the } \\
\text { building. } \\
\text { High disruption based on location involves } \\
\text { drilling of holes in the existing buildings. }\end{array}$ \\
\hline $\begin{array}{l}\text { Addition of } \\
\text { braces }\end{array}$ & $\begin{array}{l}\text { Increases lateral strength } \\
\text { and stiffness of a storey } \\
\text { substantially. } \\
\text { Increases ductility. } \\
\text { Increases lateral strength }\end{array}$ & $\begin{array}{l}\text { Connection of braces to an existing } \\
\text { frame can be difficult }\end{array}$ & $\begin{array}{c}\text { Passive energy dissipation devices can be } \\
\text { incorporated to increase damping/stiffness } \\
\text { or both }\end{array}$ \\
\hline $\begin{array}{l}\text { Addition of } \\
\text { frames }\end{array}$ & $\begin{array}{l}\text { and stiffness of the } \\
\text { building. } \\
\text { May increase ductility. }\end{array}$ & Needs adequate foundation. & $\begin{array}{l}\text { Needs integration of the frames to the } \\
\text { building }\end{array}$ \\
\hline
\end{tabular}

Nechevska Cvetanovska G., Roshi A., Bojadjieva, J. 
Table 3 Comparative evaluation of the local retrofit strategies

\begin{tabular}{|c|c|c|c|}
\hline Strengthening strategy & Merits & Demerits & Comments \\
\hline Concrete jacketing & $\begin{array}{l}\text { Increases flexural and } \\
\text { shear strength and ductility } \\
\text { of the member. } \\
\text { Easy to analyze. } \\
\text { Compatible with original } \\
\text { substrate. }\end{array}$ & $\begin{array}{l}\text { Size of the member } \\
\text { increases. } \\
\text { Anchoring of bars for } \\
\text { flexural strength; } \\
\text { Involves drilling ofholes in } \\
\text { the existing concrete. } \\
\text { Needs surface preparation } \\
\text { of the existing member. }\end{array}$ & $\begin{array}{c}\text { Low cost. } \\
\text { High disruption. } \\
\text { Experience of traditional RC } \\
\text { construction is adequate. }\end{array}$ \\
\hline $\begin{array}{l}\text { Steel jacketing of } \\
\text { columns }\end{array}$ & $\begin{array}{l}\text { Increases shear strength } \\
\text { and ductility. } \\
\text { Minimal increase in size. }\end{array}$ & $\begin{array}{l}\text { Cannot be used for } \\
\text { increasing the flexural } \\
\text { strength. } \\
\text { Needs protection against } \\
\text { corrosion and fire. }\end{array}$ & $\begin{array}{c}\text { Can be used as a } \\
\text { tem porary measure after an } \\
\text { earthquake. } \\
\text { Cost can be high. } \\
\text { Low description. } \\
\text { Needs skilled labor. }\end{array}$ \\
\hline $\begin{array}{c}\text { Bonding steel plates to } \\
\text { beams }\end{array}$ & $\begin{array}{l}\text { Increases either flexural or } \\
\text { shear strengths. } \\
\text { Minimal increase in size. }\end{array}$ & $\begin{array}{l}\text { Use of bolts involves drilling } \\
\text { in the existing concrete. } \\
\text { Needs protection against } \\
\text { corrosion and fire. }\end{array}$ & $\begin{array}{l}\text { More suitable for } \\
\text { strengthening against } \\
\text { gravity loads. } \\
\text { Cost can be high. } \\
\text { Low disruption. } \\
\text { Needs skilled labor. }\end{array}$ \\
\hline $\begin{array}{c}\text { Fiber Reinforced Polymer } \\
\text { wrapping }\end{array}$ & $\begin{array}{l}\text { Increases ductility. } \\
\text { May increase flexural or } \\
\text { shear strength. } \\
\text { Minimal increase in size. } \\
\text { Rapid installation. }\end{array}$ & $\begin{array}{l}\text { Needs protection against } \\
\text { fire. }\end{array}$ & $\begin{array}{l}\text { Cost can be high. } \\
\text { Low description. } \\
\text { Needs skilled labor. }\end{array}$ \\
\hline
\end{tabular}

\section{References}

[1] Eurocode 8: Design of Structures for Earthquake Resistance - Part 1: General Rules, Seismic Actions and Rules for Buildings.

[2] CEN 2004, European Standard EN 1998-3: 2005 Eurocode 8: Design of Structures for Earthquake Resistance. Part3: Assessmentand Retrofiting of Buildings.

[3] Nechevska-Cvetanovska, G. 1998: Non-Linear Analysis and Design of RC Cross-Section Resistance of RC Building", published September 1998.

[4] Ozcebe, G.; Ersoy, U.; Tankut, T.; Akyuz, U.; Erduran, E. 2004: Rehabilitation of Existing RC Structures Using CFRP Fabric", Proceedings of the 13th World Conference on Earthquake Engineering, Vancouver, Canada, Paper No. 1393.

[5] Earthquake-Resistant Construction of Adobe Buildings (available in Spanish and English) EERI Publication \# WHE2006-01 (published on the web in 2003; hard copy in 2006).

[6] DI Ludovico, M.; Prora, A.; Manfredi, G.; Gosenza, E. 2007: Seismic Strengthening of an Under-design RC Structure with FRP, Department of Structural Engineering, University of Naples Federico II, Naples, Italy, Published online 24 August 2007 in Wiley InterScience;

[7] CNR-DT 200/2004. Guide for the Design and Construction of Externally Bonded FRP Systems for Strengthening, 2004 http://mww.cnr.it/sitocnr//ICNR/Attivita/NormazioneeCertificazione/NormazioneeCertificazione file//struzioniCNR DT200 2004 eng.pdf(Accessed 20 December, 2019)

[8] Abbas, M. 2012: Earthquake_Resistant Structures-Design, Assessment and Rehabilitation, IntechOpen, https://doi.org/10.5772/2460

[9] Handbook on Seismic Retrofit of Buildings, April 2007, Indian Institute of Technology-Madras.

[10] Ferracuti, B.; Savola, M.; Francia, R.; Pinho, R.; Antoniou, S. 2007: Push-over Analysis ofFRP-Retrofitted Existing RC Frame Structures, University of Patras, Patras, Greece, July 2007.

[11] Fardis, M. N. 2009: Seismic Design, Assessment and Retrofiting of Concrete Buildings, Department of Civil Engineering, University of Patras, Greece, 2009. 
[12] Hollaway, L. C.; Leeming, M. B. 2000: Strengthening of Reinforced Concrete Structures Using Externally-Bonded FRP Com posites in Structural and Civil Engineering, CRC Press LLC, 2000 Corporate Blvd, NW.

[13] Hollaway, L.C.; Teng, J.G. 2008: Strengthening and Rehabilitation of Civil Infrastructures Using Fibre-Reinforced Polymer (FRP) Composites. Woodhead Publishing Limited and CRC Press LLC.

[14] Gavrilovic, P. 2005: Repair and Strengthening ofBuilding Structures. lecture notes, Institute of Earthquake Engineering and Engineering Seismology, Skopje 2005.

[15] Yan, Z.; Pantelides, C.P. 2007: Design-Oriented Model for Concrete Columns Confined with Bonded FRP Jackets or Post-Tensioned FRP Shells. Triantafillou TC (ed) 8th International Symposium on Fiber Reinforced Polymer Reinforcem entfor Concrete Structures (FRPRCS-8), Patras, GR, paper 6-1.

[16] Jones, I.A; Owen, M.J.; Middleton, V. 2000: Integrated Design and Manufacture Using Fibre-Reinforced Polymeric Composite. CRC Press LLC, Cambridge, England, 2000.

[17] MarketDevelopment Alliance of the FRP Composites Industry, Copyright 2000-2001 MarketDevelopmentAlliance of the FRP Com posites Industry. http://mww.m dacomposites.org/Manufacturing.htm (Accessed 20 December 2019.)

[18] Ko, F.K.; Du, G.W. 1998: Handbook of Composites-Textile Preforming. Chapman and Hall, 1998, London, England.

[19] Prota, A. 2014: Innovative Building Materials. lecture notes, Department of Structural Engineering, University Federioo II, Naples, 2014.

[20] Di Ludovico, M. 2013: Design and Retrofit of RC Constructions. lecture notes, Department of Structural Engineering, University of Naples Federico Il, 2013.

[21] Mazzolani 2009: Protection of Historical Buildings. PROHITECH 09, Taylor \& Francis Group, London.

[22] NATO SAP 977231 Project: Seismic Assessment and Rehabilitation of Existing Buildings, NATO Science Series.

[23] Micov, V.; Tashkov, Lj.; Krstevska, L.; Salic, R.; Jekic, G. 2010: Diagnosis of Existing State and Strengthening Solution for 180m High Reinforced Concrete Chimney. 14 ECEE, Ohrid 30.08.2010-03.09.2010.

[24] Krstevska, L.; Tashkov, Lj.; Gramatikov, K.; Landolfo, R.; Mammana, O.; Portioli, F.; Mazzolani, F. 2010: Large Scale Experimental Investigation on Mustafa-Pasha Mosque. Journal of Earthquake Engineering, 14 (6), pp. 842-873. https://doi.org/10.1080/13632460903338528

[25] Fajafar, P.; Eeri, M. 2000: A Nonlinear Analysis Method for Perfromance Based Seismic Design. Earthquake Spectra, 16 (3), pp. 573 - 592. https://doi.org/10.1193/1.1586128

[26] Priestly, M. J. N.; Calvi, G. M.; Kowalski, M. 2007: Direct Displacement-Based Seismic Design of Structures. NZSEE Conference, NewZeland.

[27] Fajafar, P. 2000: Capacity Spectrum Method Based on Inelastic Demand Spectra. Earthquake Engineering and Structural Dynamics, 28, 979-993. https://doi.org/10.1002/(SICl)1096-9845(199909)28:9<979::AID-EQE850>3.0.C0;21

[28] Pojani, N. 2003: Seismic Engineering. Published at TOENA, Tirana, Albania.

[29] Chopra, A. K. 2003: Dynamic of Structures. $2^{\text {nd }}$ ed. Theory and Application to Earthquake Engineering. Prentice Hall, New Jersey.

[30] Paulay, T.; Priestly, M. J. 1992: Seismic Design of Reinforced Concrete and Masonry Structures. Wiley \& Sons, ISBN 0 $-471-54915-0$.

[31] Necevska-Cvetanovska, G.; Petrusevcka, R. 2000: Methodology for Seismic Design of R/C Building Structures . 12WCEE.

[32] Danilovski, D. G.; Necevska-Cvetanovska, G.; Trenskovski, K.; Petrusevska, R. 2000: Seismic Resistance of High Strength R/C Members.12WCEE.

[33] European Committee. Eurocode - 2: Design of concrete structures. Part 1-1: General rules and rules for buildings. English version, December 2004.

[34] Demonstration of efficiency of seismic retrofit with CFRPS trough full scale site testing of substandard RC structures https://mww.youtube.com/watch?v=Mul9fNgvi2A (Accessed 20 December 2019)

Please cite this article as:

Nechevska Cvetanovska, G.; Roshi, A.; Bojadjieva, J.: Seismic strengthening of existing Rc buildings structures using concrete jacketing and FRP materials, Electronic Journal of the Faculty of Civil Engineering Osijek-e-GFOS, 2019, 19, pp. 68-80, https://doi.org/10.13167/2019.19.7 